\title{
Evaluation of Information Quality Kupang City Government Website
}

\author{
Aryanthy Sintikhe Elizadon Puling \\ Information System, Kristen Satya Wacana University, \\ Salatiga, 50715, Indonesia \\ 682018711@student.uksw.edu
}

\author{
Melkior N.N Sitokdana \\ Information System, Kristen Satya Wacana University, \\ Salatiga, 50715, Indonesia \\ melkior.sitokdana@uksw.edu
}

\begin{abstract}
Kupang Municipal Government long enough to have a website with a domain name v8.kupangkota.go.id. In this research will be used a descriptive qualitative method, which describes and illustrate the content Government website that have been set by the Ministry of Communications and the use of 10 (ten) dimension of the quality of information that is Accuracy, Consistency, Punctuality, Completeness, Reliability, Availability, Relevancy, Credibility, Efficiency and Value-Added. Based on the results of the evaluation of the quality of Kupang City Government Website information, it can be concluded that the website was not fully present enough quality information for the public. There are still some shortcomings such as the lack of an increase in accuracy of presentation of information, the lack of consistency in the presentation of information as there are pages in which there are three (3) categories that are not accessible or not there is any information. The website is expected to not only serve as a source of information that is passive but dynamic so that the function and role of the website reciprocal effect. In addition, the provincial government should continue to ensure data is always updated and complete, permanent increase in the added value of public services and still make the website as the main medium of public information services.
\end{abstract}

Keywords-Evaluation, Descriptive, Qualitative, Information Quality, Website, Kupang City.

\section{INTRODUCTION}

The rapid development of technology makes every person and organization entering the technology flow must keep pace with changes. Changes that occur are done as an anticipation in the face of competition. According to Marshall, McLuhan technology is an important factor in supporting the performance of individuals and organizations in increasing the effectiveness and efficiency of information. The central government to the regional government, in this case, utilizes the development of information technology to improve services to the public in a way in the form of eGovernment services to the community, both in the context of the relationship between government to government $(\mathrm{G} 2 \mathrm{G})$, government to business $(\mathrm{G} 2 \mathrm{~B})$.
The purpose of implementing e-Government is not only to discuss agreements, but rather the demand for requirements that must be met by the Government to serve the public, and manage government administration. Because, at this time we are in an era of Information Technology that can be juxtaposed with the primary requirement, so management organizations must adapt to this development by always creating and innovating to provide excellent services to the community. Current public demands are more effective and efficient services so that the implementation of e-government is absolutely applied in every level of government organization.

By implementing e-Government, it will certainly implement good governance and clean governance because the implementation of e-Government is proven to facilitate approval, efficiency, approval, accountability, responsibility, and public participation. One of the most important e-government services for connecting government with the public is the website. Thus, the Kupang city government provides electronic services consisting of Local Government Websites with domains (http://v8.kupangkota.go.id/). Almost all levels of government in Kupang City already have a website but still, found an implementation that has not been maximized in the implementation of real-time information on the Kupang City Government website. For this reason, this research was conducted to test the quality of information on the Kupang City government website. Based on the description above, the proposed objective is interested in "Evaluation of Information Quality on the Kupang City Government Website". With this, it can be expected that the Kupang City Government website has an information service contribution to the public of Kupang City. For this reason, research is conducted to measure organizational performance and to be carried out on the Kupang City Government Website with 10 (ten) dimensions of information quality, namely: Accuracy, Consistency, Punctuality, Completeness, Reliability, Availability, Relevancy, Credibility, Efficiency and Value-Added. 


\section{LITERATURE REVIEW}

\section{A. Prior Research}

Research on the topic of evaluating Local Government Websites in Indonesia is not a new topic, several previous researches used as a reference in this research, among others;

The research entitled Evaluation of e-Government Implementation on the Surabaya City Government Website, Medan City, Banjarmasin City, Makassar City, and Jayapura City, several indicators are used to improve the quality of the Website, namely supported aspects, services, efficiency, economy, aspirations, appearance, update, and Stage of completion of e-Government objectives. the result was concluded that: Surabaya is much better than in other cities. These results are the same as the PeGi evaluation from 2012-2014 on the egovernment website ranking website so far only discussed by the government in Java. For this reason, it is recommended several things to improve the quality of eGovernment Websites, namely the improvement of the Website content, but previously aspects of e-Leadership, Information Network Infrastructure, Information Management, Business Environment, Society and Human Resources can be formulated properly in the form of Strategic Plan For development and implementation to be carried out in full and on target (Sitokdana, Melkior, 2015).

The research entitled "Evaluation of Information Quality Salatiga City Government Website". The Salatiga City Government has long had a Website with the address http://www.salatiga.go.id/. In implementation and utilization, it still encountered various problems, particularly in availability relating to the quality of information on the website. Therefore, the purpose of this research was to evaluate the quality of information on the website and provide recommendations to the Salatiga City Government to improve the quality of information service. The research was conducted using qualitative descriptive methods with observation data retrieval techniques on the contents of the website and literature studies. The data collected was collected using 10 indicators of information quality, namely Accuracy, Consistency, Punctuality, Completeness, Reliability, Availability, Relevancy, Credibility, Efficiency and Value-Added. Based on the results of the quality assessment of information on this website, it can be concluded that the Salatiga City Government has provided adequate quality information to the public and meets the standards set by the Ministry of Communication and Information. However, it still has shortcomings in terms of updating information and data in real-time (every day) and still inconsistent in the presentation of information (Sarmento J.M.B Prisca, Sitokdana N.N. Melkior and Tanaem F. Penidas, 2019).

The research entitled "Evaluation of Information Quality Bitung City Government Website" Based on the results of the analysis and assessment using 10 (ten) dimensions of information quality, namely: Accuracy, Consistency, Punctuality, Completeness, Reliability,
Availability, Relevancy, Credibility, Efficiency and Value-Added. It can be concluded that in general, the quality of Bitung City Government website is good enough. Some deficiencies found in general that an error caused by links that lead to blank pages. Based on this result, several things that become suggestions from researchers are the City Government of Bitung should always improve the accuracy of information presentation; consistent in presenting the information with display the previous information; make sure the data is always complete and clear; make sure confirm earlier notifications when maintenance; present added value to attract public interest and create a website https://bitungkota.go.id/ as the main media of public information services Bitung City (Kambey J.F. Dean and Sitokdana N.N Melkior, 2020).

Based on the result of the evaluation of information quality e-Government Website the Provincial Government of East Nusa Tenggara, Maluku, North Maluku, West Papua and Papua using 10 (ten) dimensions, namely: Accuracy, Consistency, Punctuality, Completeness, Reliability, Availability, Relevancy, Credibility, Efficiency and Value-Added can be concluded that all websites not enough to provide quality information to the public. To that end, each website recommended several things, namely the Provincial Government should always improve the accuracy of information presentation, consistency in the presentation of public information services. Make sure the data is always updated and complete, ensuring data is always available, increasing the value-added in public services, and make the website as a medium the main public information service. While suggestions for future research examine the analysis of public satisfaction from the aspect of System Quality and Service Quality on the Websites of each Province. Then do the comprehensive analysis with other Provincial government website in Western Indonesia which has the best quality eGovernment Website. Thus, it would appear gap eGovernment Website quality among the best in the West Indonesian Region with East Indonesia Region. (Sitokdana M. N. N. 2019, October).

\section{B. Information System}

Information systems are ways that are organized to collect, enter, and process and store data, and ways that are organized to store, manage, connect, and report information that regulates so as to make an organization can obtain the goals that have been provided concluding the system information is a collection of resources in an organization, whether in the form of people, hardware, software, communication networks that are interconnected to collect and process data into useful information for users of information in an organization. (Krismaji, 2015).

\section{E-Government}

E-Government is an effort to use information and communication technologies to improve efficiency and effectiveness, transparency, and accountability of government in providing better public services (Falih 
Suaedi, Bintoro Wardianto, 2010). then, according to Ministry of Communication and Informatics Samodra Wibawa (1994) defines e-Government as public services are organized through government websites whose domain is used also show the Indonesian government domain (go.id). Rianto, Budi et al (2019) concluded that e-Government is a form of application implementation and governance tasks using telematics technology or information and communication technology. EGovernment applications provide opportunities to improve and optimize the relationship among government agencies, the relationship between government and business world, and society. The mechanism that relationship through the use of information technology which is a collaboration or a merger between the computer and network communications systems (Wiriyanti et al 2015).

\section{Information Quality}

According to Suwardjono (2001, p.58) quality of information is the inherent characteristic of the information so that the information is meaningful to the user and to give assurance to users so useful in the decision. According to Ariyanto and Desika (2007) quality of information is a measure of the value of the existing needs and has been established from the data organized and processed to create a form that is meaningful to users. Leung concludes that information quality is measured through the number of dimensions in six (6) Functional categories namely, Reliability, Usability, Efficiency, Treatment, and Portability. While Shanks \& Corbitt (1999) also found the quality of the information measured by the number of dimensions in four (4) categories: Syntactic, Semantics, Pragmatics, and Social Affairs. Based on the theories is the quality of information is the inherent characteristics of the information so that information is meaningful to the user and gives confidence to the user to use the information (Wati, P. R. 2015).

\section{RESEARCH METHODS}

The research on evaluating information quality on the website of Kupang City Government uses a qualitative descriptive method. A descriptive qualitative research method is a method used by researchers to find knowledge or theory of research at one particular time. The qualitative research method itself is a descriptive research method, uses analysis, refers to data, utilizes existing theories as supporting material, and produces a theory. While the descriptive research methods can be interpreted as problem-solving procedures that are investigated by describing the state of the subject or object in the study can be in the form of people, institutions, communities, and others who are based on the facts that appear or as is (Mukhtar, 2013). In the context of this research is to describe the quality of information on the e-Government website of Kupang City. The analyzed data were taken from secondary data sources, namely a study of literature, articles, journals, and an in-depth search of the quality of information on the e-Government website of Kupang City "NTT" government. The data collected is measured by using 10 (ten) indicators of information quality, namely Accuracy, Consistency, Punctuality, Completeness, Reliability, Availability, Relevancy, Credibility, Efficiency and Value-Added

\section{RESULTS AND DISCUSSION}

\section{A. Local Government Website Standards Analysis}

In this section, we will discuss the application of egovernment at the Kupang City Government website, and does it meet the minimum standards for the Regional Government Website set by the Ministry of Communication and Information? To discuss the implementation of e-government to evaluate the current website on August 2, 2019. The following is the main appearance of the Kupang City Government website. www. v8.kupangkota.go.id

\section{Kupangkota.go.id}

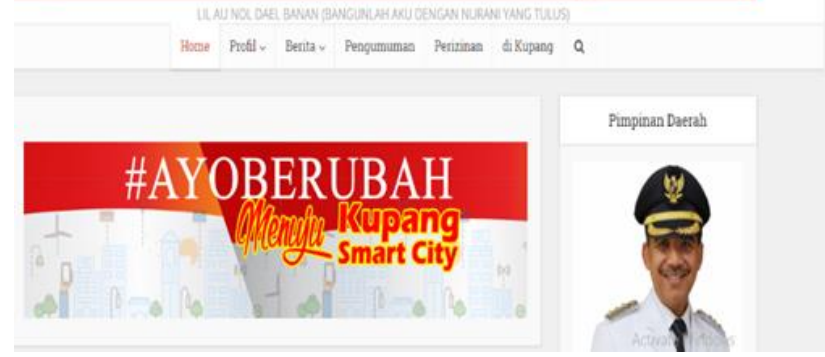

Figure 1. Main Page Display of Kupang City Government Website.

Based on figure 1. It appears that there are 6 Website page menus, namely Home, Profile, News, Announcements, Licensing, and in Kupang. Each page can be explained as follows; (1) Home is the main view of the Website. This page displays the Vision \& Mission, History of Kupang City. Besides that, it also displays archived document links by year and news categorization, namely Transparency, Transportation, Nature Tourism, Maritime Tourism, Cultural Tourism, Gallery, Announcement, and Education. (2) Profile is the second display Website that contains 8 links consisting of the History Kupang City, Motto, and Emblem of Kupang City, Vision, and Mission, Administrative Region, Profile Mayor of Kupang, Profile Deputy Mayor of Kupang, Regional Apparatus, RPJMD of Kupang City 2017-2022. (3) News is the third view of websites that contain 3 links consisting of Health Info, Technology, Meditations. (4) Announcements is the fourth appearance of the Website which contains Categories from various announcements. (5) Licensing is the fifth website display that is directly linked to another page, namely www.http: //dpmptsp.kupangkota.go.id/ which contains the Office of Investment and Integrated Services of One Door in 
Kupang City. On the Website, there are 6 menu pages namely Home, News, Investment, Licensing Services, Profiles, and Activities (Sufriyadi, 2014). (6) in Kupang contains new links in which there are 8 Website pages, which are the Home which contains Breaking News, various Event and Tourism links. The second page is Breaking News, Events, Points of Interest, Tourism, UMKM, Promotion, and Licensing.

After discussing the implementation of e-government, the next is to evaluate whether the Government of Kupang City has met the minimum standards Local Government Website predetermined the Ministry of Communication and Information? Referring to this standard, the content that must be on the Local Government Website is Brief, Regional Government, Geography Map of Regions and Resources, Regional Regulation / Policy and Guest Book. The content standard used as the main reference in assessing the Kupang City Government website. The following are the results of the analysis and recommendations of researchers based on the standards set by the Ministry of Communication and Information, namely;

a) Overview, which is explained briefly about the existence of the relevant Regional Government (history, regional motto, symbol and the symbolic meaning, location in map form, vision and mission). "On Kupang City Government website already provided everything, but in a location or administrative area have not been provided with a map depicting the presence of Kupang City. Supposedly pages administrative areas should be included in the form of a map of the location".

b) Regional Government, namely explaining the existing organizational structure in the relevant Regional Government (executive, legislative) along with the name, address, telephone, e-mail from the regional official. If possible, the biodata of the regional leadership will be displayed therefore allows the public to know.

"On Kupang City Government Website does not have an organizational structure, but on the profile page, there is a sub-menu that contains profiles of the two Regional Leaders along with the biodata of each leader. Supposedly the organizational structure should be created on the profile page so that the public can find out".

c) Geography, which explains among others about the topographical, weather demographic, and climatic, social, and economic, the culture of the region. All the data in the form of the numerical or statistical must include the department name and the data source.

"On the Kupang City Government Website, there is no special page to display about Geographics and related content in question. The recommendation was made a separate page or enter a sub-page Overview / Regional Profile”.

d) Map of Regions and Resources, which contains administrative boundaries in the form of regional maps (agreed to use reference maps issued by the
National Coordinating Survey and Mapping Agency-Bakosurtanal Mapping, or related government agencies that provide tasks and map makers), Also Resources Required by the Region Determined in the form of Resources (used by the reference map issued by the government which has the main duties and functions of the map maker) that can be used for the needs of users.

"On the Kupang City Government Website, there is no specific page to display about the Regional Map and Resources and related content in question. The recommendation was made a separate page or enter a sub-page Overview / Regional Profile".

e) Regional Regulations / Policies, namely; Explain the Regional Regulation "Perda" that has been issued by the proposed Regional Government. It is through this regional government website that all of the "Perda" that have been issued can be socialized to the public.

"On the Kupang City Government Website, there is no specific page on Regional Regulations / Policies, but the content is also included in the home page which contains transparency below containing the annual APBD link, from 2013 to 2018. Each link contains an attachment government policy of Kupang City along with the funds released. The recommendation is to simply create a special page for policies that have been made by the government and increase Transparency again by conducting Publication of OPD Performance".

f) Guest Book, which is a place to receive input from users of the recipient local government website.

"On the Kupang City Government Website, there is no guest book. My suggestion should be made for a special page to be made accessible to the public to provide input to the Kupang City government such as Email, Telephone Number, etc".

Based on the evaluation results using the Local Government Standards Website instrument established by the Ministry of Communication and Information, it can be concluded that the Kupang City Government Website has not fully met the standards. The available Menus and sub-menus are still limited 
B. Quality Analysis Kupang City Government Website

Tabel 1. Analysis of Website Information Quality

\begin{tabular}{|c|c|c|c|}
\hline No & $\begin{array}{l}\text { Information } \\
\text { Quality } \\
\text { Dimension }\end{array}$ & Evaluation & Recommendation \\
\hline 1. & Accuracy & $\begin{array}{l}\text { There are some errors in this case on the news pages are not included } \\
\text { news updates. News is updated is only loaded on the Home page. }\end{array}$ & $\begin{array}{l}\text { Supposedly news on updates must attach } \\
\text { to a special news page. }\end{array}$ \\
\hline 2. & Consistency & $\begin{array}{l}\text { There is some information presented has not been consistent. As in the } \\
\text { News page, which contains three ( } 3 \text { ) categories that have not found any } \\
\text { information. But the latest news information has been updated } \\
\text { consistently }\end{array}$ & $\begin{array}{l}\text { Supposedly on the news page only } \\
\text { contains the latest important news. } 3 \\
\text { categories that already exist, created in a } \\
\text { different menu. }\end{array}$ \\
\hline 3. & Punctuality & $\begin{array}{l}\text { So far, the information is updated only from } 2018 \text { to } 2020 \text {. In addition, } \\
\text { the news frequently updated every } 2 \text { days and already complete. }\end{array}$ & $\begin{array}{l}\text { Still maintain timeliness in news updates. } \\
\text { And suggested there should be a news } \\
\text { update to the old order can be made } \\
\text { comparative progress of development. }\end{array}$ \\
\hline 4. & Completeness & $\begin{array}{l}\text { Data and information presented are still incomplete. There are several } \\
\text { menus whose information is still empty and the contents do not meet } \\
\text { the Ministry of Communication and Information standards. }\end{array}$ & $\begin{array}{l}\text { Must be completed with every content } \\
\text { whose data and information are still } \\
\text { incomplete }\end{array}$ \\
\hline 5. & Reliability & The information presented is reliable although some incomplete & $\begin{array}{l}\text { Always update data and information } \\
\text { regularly so that the Website can be used } \\
\text { as a primary means of public information }\end{array}$ \\
\hline 6. & Availability & $\begin{array}{l}\text { Data and information can be accessed at any time unless there is } \\
\text { interference or improvement on the website itself. }\end{array}$ & $\begin{array}{l}\text { Always make sure data and information } \\
\text { remain available. }\end{array}$ \\
\hline 7. & Relevance & $\begin{array}{l}\text { The data and information presented are quite relevant, except on the } \\
\text { Menu of the News page where there is no information. }\end{array}$ & $\begin{array}{l}\text { Always provide information relevant to } \\
\text { public needs. }\end{array}$ \\
\hline 8. & Credibility & $\begin{array}{l}\text { Data and information presented are trustworthy. Because every } \\
\text { information is presented directly from the source. }\end{array}$ & $\begin{array}{l}\text { Keep serving reliable information so you } \\
\text { can always convince the public. }\end{array}$ \\
\hline 9. & Efficiency & Data and information are already quite useful for the public. & $\begin{array}{l}\text { Make sure the website continues to } \\
\text { provide benefits to the public }\end{array}$ \\
\hline 10. & Value-Added & $\begin{array}{l}\text { Data and information provided are sufficient to provide value-added. } \\
\text { Looks at every link on each menu are easily accessible. Although there } \\
\text { is still some information that is not accessible. }\end{array}$ & $\begin{array}{l}\text { The website should add a link for the } \\
\text { Guest Book so that website visitors can } \\
\text { provide an entry. }\end{array}$ \\
\hline
\end{tabular}

Thus, based on the evaluation results of the quality of the information system using 10 (ten) dimensions in table 3 , it can be seen that the Kupang City Government Website still found some deficiencies so that it is still said to be inconsistent and does not fully meet the Ministry of Communication and Information standards. Therefore, the table above has shown recommendations that can be used as a reference in developing the Kupang City Government Website.

\section{CONCLUSION}

Based on the evaluation results of the information quality of the Kupang City Government website using 10 (ten) dimensions, namely Accuracy, Consistency, Punctuality, Completeness, Reliability, Availability, Relevancy, Credibilty, Efficiency, and Value-Added. It can be concluded that the website has not fully provided enough quality information for the public. There are still some deficiencies such as the lack of increased accuracy in the presentation of information, the absence of consistency in the presentation of information such as there are pages in which there are 3 categories that cannot be accessed or there is no information whatsoever, then the news is only found in the front view of the website. The website is expected to not only function as a passive source of information but be dynamic so that the functions and roles of the website are bi-directional or there are reciprocal effects. In addition, the provincial government must continue to ensure that data is always up-to-date and complete while increasing value-added in public services and still make the website as the main media for public information services.

\section{REFERENCES}

Ariyanto dan Desika (2007, user. Leung (2001) Pengaruh Efektivitas Penggunaan Dan Kepercayaan Teknologi Sistem Informasi Akuntansi Terhadap Kinerja Individual. Jurnal Akuntansi Dan Bisnis 3(1): 23.

Falih Suaedi dan Bintoro Wardiyanto. 2010. Revitalisasi Administrasi Negara, Reformasi Birokrasi dan EGovernance.Yogyakarta: Graha Ilmu

Kambey J.F. Dean dan Sitokdana N.N Melkior (2020). Evaluasi Kualitas Informasi Website Pemerintah Kota Bitung

Krismaji. 2015. Sistem Informasi Akuntansi. Yogyakarta. UPP STIM YKPN

Mukhtar. 2013. Metode Penelitian Deskriftif Kualitatif. Jakarta: GP Press Group

Rianto, Budi., Tri Lestari. 2012. Polri \& Aplikasi EGovernment dalam Pelayanan Publik. Surabaya: CV. Putra Media Nusantara (PMN).

Samodra Wibawa dkk. 1994. Evaluasi Kebijakan Publik. Jakarta: PT. Raja Grafindo Persada.

Sarmento J.M.B Prisca, Sitokdana N.N. Melkior dan Tanaem F. Penidas (2019). Evaluasi Kulitas Informasi Website Pemerintah Kota Salatiga

Shanks, G. dan Corbitt, B. 1999. Understanding Data Quality: Social dan Culture Aspects. Dalam Proceedings of the 10th Australasian Conference of Information System.

Sitokdana, M. N. N. (2015). "Evaluasi Implementasi eGovernment pada Website Pemerintah Kota Surabaya, Kota Medan, Kota Banjarmasin, Kota Makassar dan Kota Jayapura". Jurnal Buana Informatika, 6(4). 
Sitokdana M. N. N. (2019, oktober). "Evaluasi Kualitas Informasi Website e-Government Pemerintah Provinsi Wilayah Indonesia Timur (Studi Kasus: Provinsi NTT, Maluku, Maluku Utara, Papua Barat dan Papua)", Atlantis Press.

Sufriyadi, M. (2014). "Analisis Pengembangan eGovernment dalam pelayanan pajak kendaraan bermotor Dinas Pendapatan Provinsi Riau di Kantor Unit Pelaksana Teknis Pendapatan Pekanbaru Selatan", Skripsi thesis, Universitas Negeri Sultan Syarif Kasim Riau.

Suwardjono (2001, p.58) Teori Akuntansi. BPFE. Yogyakarta

Wati, P. R. (2015) "Pengaruh Kualitas Sistem Informasi Informasi, Perceived Usefulness dan Kualitas Informasi Terhadap Kepuasan Pengguna Sistem Informasi Akuntansi (Studi Kasus PT. Kereta Api Indonesia (Persero) Bandung)", Skripsi (S1) Pengaruh Kualitas Sistem Informasi, Perceived Usefulness, dan Kualitas Informasi Terhadap Kepuasan Pengguna Sistem Informasi Akuntansi (Studi Pada PT Kereta Api Indonesia (Persero) Bandung). Skripsi(S1) thesis, Fakultas Ekonomi Unpas.

Wiriyanti, Desy. (2015). "Analisis Sistem Informasi Akuntansi atas siklus pendapatan pada PT. (GMF AEROASIA).

(https://widuri.raharja.info/index.php?title=KP132237 7489\#: :text=Menurut\%20Krismiaji\%20(2015\%3A1 6),sehingga $\% 20$ sebuah $\% 20$ organisasi $\% 20$ dapat $\% 20 \mathrm{~m}$ encapa) 